\title{
СЦЕНІЧНА ДІЯЛЬНІСТЬ ЗОЇ ХРИСТИЧ У КОНТЕКСТІ РОЗВИТКУ ВОКАЛЬНОГО МИСТЕЦТВА УКРАЇНИ
}

\section{ЛIТЕРАТУРА}

1. Закон України "Про запобігання та протидію домашньому насильству” від 7 грудня 2017 р. №2229VIII. URL: http://www.rada.gov.ua.

2. Методичний посібник для фахівців, які впроваджують корекційні програми для осіб, які вчинили насильство в сім'ї/ уклад.: Г.Ю. Мустафаєв, І.І. Довгаль. К., 2011. 192 с.

3. Постанова Кабінету Міністрів України від 22.08. 2018 p. № 655 “Про затвердження Типового положення про притулок для осіб, які постраждали від домашнього насильства та/або насильства за ознакою статі". URL: https://www.kmu.gov.ua/.../pro-zatverdzhennyatipovogo-polozhennya-pr.

4. Статистика, що шокує. URL: http://pedpresa.com.ua/ 35469-domashnje-nasylstvomovoyu-tsyfr.html.

5. Трубавіна I. М. Соціальний супровід неблагополучної сім'ї. Науково-методичні матеріали. К. ДЦССМ. 2003. 86 c.

\section{REFERENCES}

1. Zakon Ukrainu "Pro zapobigannya ta protydiju domashnjomu nasylstvu" vid 7 grudnya 2017 roku №2229VIII [The Law of Ukraine "On Prevention and
Counteraction of Domestic Violence" from 9 December 2017]. Available at: http://www.rada.gov.ua. [in Ukrainian].

2. Metodychnyi posibnyk dlja fachivtsiv, jaki vprovadzhujut korektsijni programy dlya osib, jaki vchynyly nasilstvo v simiji (2011). [Methodological manual for specialists, that implement remedial programs for persons committing domestic violence]. (Ed.). H.Y.Mustafaev, I.I.Dovhal. Kyiv, 192 p. [in Ukrainian].

3. Postanova Kabinety Ministriv Ukrainy vid 22.08.2018p. №655 "Pro zatverdzhennya Typovogo polozhennja pro prytulok dlja osib, jaki postradaly vid domashnogo nasylstva ta/abo nasylstva za oznakoju statti" [Resolution of Cabinet of Ministers of Ukraine from 22 August 2018 №655 “On Approval of Typical Position on Shelter for People Suffered from Domestic Violence and/or Violence Based on Gender"]. Available at: http://www.kmu.gov.ua/.../prozatverdzhennya-tipovogo-polozhennya-pr. [in Ukrainian].

4. Statustyka, cho shokuje [Statistics that Shocks]. Available at: http://pedprese.com.ua/35469-domashnjenasylstvomovoyu-tsyfr.html. [in Ukrainian].

5. Trubavina, I.M. (2003). Sotsialnyi suprovid neblagopolychnoji simji [Social Convoy of Dysfunctional Family]. Scientific and methodological materials. Kyiv, 86 p. [in Ukrainian].

Стаття надійшла до редакції 10.02.2021

УДК 782.071.2(477)

DOI:

Ірина Кліш, доцент кафедри народних музичних інструментів та вокалу Дрогобицького державного педагогічного університету імені Івана Франка

\section{СЦЕНІЧНА ДІЯЛЬНІСТЬ ЗОЇ ХРИСТИЧ У КОНТЕКСТІ РОЗВИТКУ ВОКАЛЬНОГО МИСТЕЦТВА УКРАЇНИ}

У статті розкривається конкурсна, концертно-виконавська і педагогічна, діяльність украӥнської співачки Зої Христич (сопрано), народної артистки Украӥни, солістки Київського театру опери та балету імені Т. Г. Шевченка. Висвітлюється широка палітра ї̈ участі у міжнародних вокальних конкурсах у Женеві (Швейчарія, 1956, диплом I ступеня), Відні (Австрія, 1959, перша премія і золота медаль), Тулузі (Франиія, 1962, срібна медаль і звання лауреата), Софії (Болгарія, 1963), всесвітньому фестивалі демократичноїмолоді i студентів у Відні (1959). Подається опис ї̈ концертних виступів і оперних спектаклів, розкривається репертуар співачки і значення ї̈ творчості у розвитку музичного мистецтва Украӥни другої половини ХХ ст.

Ключові слова: Зоя Христич; співачка; концертна практика; оперне мистецтво; вокальні конкурси; гастролі; репертуар.

Jim. 8.

Iryna Klish, Associate Professor of the Folk Musical Instruments and Vocal Singing Department Drohobych Ivan Franko State Pedagogical University

\section{CREATIVE HERITAGE OF ZOIA KHRYSTYCH ON STAGE IN THE CONTEXT OF DEVELOPMENT OF VOCAL SINGING ART OF UKRAINE}

The article reveals the competitive, concert performance, and teaching activity of Zoia Khrystych, a Ukrainian soprano singer, National Artist of Ukraine, solo singer of Kyiv Taras Shevchenko Theatre of Opera and Ballet. The author elaborates on the wide range of her activities, including participation on international vocal competitions in Geneva (Switzerland, 1956, diploma), Vienna (Austria, 1959, First Prize and Golden Medal), Toulouse (France, 1962, silver medal and awardee's title), Sofia (Bulgaria, 1963), $7^{\text {th }}$ World Festival of Youth and Students in Vienna (1959). The author provides a description of Zoia Khrystych's concert performances and opera plays; reveals the repertory of the singer and the importance of her creativity in the development of Ukrainian musical art in the second half of the $20^{\text {th }}$ century.

The cluster of renowned names of Ukrainian singers who have gained fame on prestigious stages across the 


\section{СЦЕНГЧНАДІЯЛЬНІСТЬ ЗОЇ ХРИСТИЧ У КОНТЕКСТІ РОЗВИТКУ ВОКАЛЬНОГО МИСТЕЦТВА УКРАЇНИ}

world includes the name of Zoia Khrystych, an alumnus of Odessa Antonina Nezhdanova Conservatoire (class of National Artist, Professor Olha Blahovydova.

The singer was performing the classical repertoire, leaving unforgettable memories with her excellent performance in various opera plays: Wolfgang Amadeus Mozart, Ruggero Leoncavallo, Giuseppe Verdi, Charles Franзois Gounod, George Bizet, Richard. Wagner, Mikhail Glinka, Piotr Illich Tchaikovsky, Vissarion Shebalin, Semen Hulak-Artemovsky, Mykola Lysenko, Mykola Arkas, Kostiantyn Dankevych, Heorhiy Maiboroda. Zoia Khrystych's chamber repertoire featured works from miscellaneous genres and eras by a multitude of composers, including Johann Sebastian Bach, Georg Friedrich Hdndel, Christoph von Gluck, W. A. Mozart, Franz Schubert, Robert Schumann, Richard Strauss, Mikhail Glinka, Piotr Illich Tchaikovsky, Nikolai Rimsky-Korsakov, Sergei Rachmaninoff, Mykola Lysenko, Kyrylo Stestenko, Yakiv Stepovy and others.

Zoia Khrystych made a number of vinyl recordings of Ukrainian folk songs, arias from operas created by Ukrainian and foreign composers. Zoia Khrystych's disciples in the National Musical Academy named after Pyotr Illich Tchaikovsky included merited maestros of singing: Lidiia Zabiliasta, Volodymyr Hryshko, Liudmyla Makovetska, Olha Kaminska, Olha Fomichova, Mary Grevtsova, Iva Nosyk et al.

Zoia Khrystych was regularly participating in multiple international competitions that took place in Ukraine and abroad. Her creative activity was exemplary in terms of her devotion to Ukrainian culture.

Keywords: Zoia Khrystych; a singer; musical competition; concert performanship; opera art; a tour; repertoire.

П остановка проблеми. Серед палітри імен видатних майстрів українського вокального мистецтва другої половини XX ст. чільна позиція належить народній артистці України Зої Христич. Її чудове, соковите ліричне сопрано своєю ніжністю і м'якістю захоплювало слухачів, як в Україні так і за їі межами.

Мета статті полягає у розкритті місця і ролі Зої Христич в розвитку музичної культури і освіти України, передусім як співачки, актриси і педагога.

Огляд останніх досліджень і публікацій. Висвітленню мистецьких надбань співачки належить доволі незначна кількість праць. Це, насамперед довідникові матеріали Івана Лисенка [4], цікавим видався творчий портрет співачки пера Е. Яворського [8], проте виданий він був ще 1975 р. Доволі фрагментарну інформацію сучасного характеру знаходимо в підручнику В. Антонюк [1], монографії О. Шуляр [7], статтях Л. Трубнікової [5]. Важливим джерелом для відтворення репертуарного різноманіття 3. Христич стала публікація нотної збірки "Українські народні пісні з репертуару Зої Христич" (Київ Музична Україна, 1975) [6].

Виклад основного матеріалу. Мистецтвом оперного співу і акторською майстерністю Зоя Христич оволоділа під керівництвом відомих майстрів: диригентів В. Тольби, О. Климова, К. Сімеонова, режисерів В. Скляренка, М. Стефановича, Д. Смолича. Значних успіхів співачка добилася і в галузі концертновиконавської діяльності. Про це свідчать ії блискучі перемоги на чотирьох міжнародних конкурсах вокалістів, за які співачка завдячувала видатному українському педагогові, народній артистці України, професору Одеської консерваторії ім. А. Нежданової - Ольз Благовидовій.
Народилася Зоя Христич у Тирасполі (Молдова) 1 листопада 1932 р. Шлях на велику сцену цієї талановитої співачки розпочався зі шкільних виступів для батьківської аудиторії у рідному місті. 3 переїздом батьків до Ленінграда (сьогодні - Санкт-Петербург) талановита дівчинка вступила на навчання до вечірньої музичної школи на вокальний відділ у клас Надії Максименко й училась наполегливо та успішно.

Незадовго батька перевели на службу до Одеси. Мама Зої, прагнучи щоб донька здобула грунтовну музичну освіту, знаючи глибокі музичні традиції міста привела ії до вечірньої музичної школи у клас вокалу до Зінаїди Салій - солістки Одеської опери, яка завжди цікаво розповідала своїм вихованцям про театр і видатних співаків, що мало значний вплив на навчання і творчий розвиток учнів. Минали роки навчання і настав час вибору майбутньої спеціальності. Батько радив доньці навчатися у медичному інституті, вона і сама мала бажання стати лікарем, проте й великою була любов до музичного мистецтва. Для розв'язання цього важливого питання родина вирішила порадитись 3 директором Одеської консерваторії відомим композитором Костянтином Данькевичем. На прослуховуванні 3. Христич співала каватину Антоніди з опери "Іван Сусанін" М. Глінки та ще кілька українських народних пісень і справила захопливе враження на митця, який порадив подавати документи на вступ до консерваторії. Після успішної здачі вступних іспитів вона була зарахована в клас професора Ольги Благовидової, яка стала для неї не тільки педагогом але й добрим другом і порадником. Професор, працюючи над вдосконаленням вокально-технічних навиків, велику увагу приділяла розвитку естетичного смаку, дбаючи 


\section{СЦЕНІЧНА ДІЯЛЬНІСТЬ ЗОЇ ХРИСТИЧУ КОНТЕКСТІ РОЗВИТКУ ВОКАЛЬНОГО МИСТЕЦТВА УКРАЇНИ}

щоб їі вихованці були не тільки здібними виконавцями, але й мислячими митцями.

Свої педагогічні здібності Зоя Христич проявила ще в студентські роки. Проходячи педагогічну практику в студії при консерваторії, Зоя Христич зустрілася зі своєю першою ученицею Людмилою Цуркан, яка після навчання у студії стала ученицею класу Ольги Благовидової, а згодом лауреатом республіканського конкурсу вокалістів і солісткою Харківського театру опери та балету ім. М. Лисенка.

Навесні 1956 р. 3. Христич зосереджено готувалася до державних іспитів. У дипломному оперному спектаклі вона виконала провідну партію Іоланти в однойменній опері П. Чайковського. Сольна програма складалася з таких творів: арія Марії з опери Г. Доніцетті “Дочка полку”, арія Леонори з опери “Трубадур” Д. Верді, арія Оксани 3 опери “Черевички” П. Чайковського і камерні твори - А. Дворжака, М. Римського-Корсакова, Р. Глієра, Ф. Надененка і дві українські народні пісні “Я в садочку була" та "Спать мені не хочеться”. Виконання випускної програми було відзначено високою оцінкою за майстерність і прекрасні вокальні дані, а після дипломної вистави 3. Христич була запрошена працювати солісткою Одеського оперного театру.

У цьому ж році було проведено республіканський огляд молодих виконавців - випускників консерваторій України. В заключному концерті від Одеської консерваторії взяли участь Бела Руденко і Зоя Христич. У рецензії на концерт "На щасливу творчу дорогу” К. Данькевич відзначив: “...Зоя Христич справді артистично виконала складну арію Леонори з опери “Трубадур” Дж. Верді. Голос молодої співачки - дзвінкий, гнучкий i виразний - ллється вільно, окрилений справжнім сердечним натхненням" [3]. Після успішного виступу Зою Христич запросили до Київського театру опери та балету імені Т. Г. Шевченка і в перший робочий день головний диригент театру О. Климов запропонував їй співати партію Наталки в опері “Наталка-Полтавка” М. Лисенка.

Вистава на той час була блискуче здійснена такими видатними майстрами: диригентом Веніамином Тольбою, режисером Володимиром Манзієм та видатним українським актором Амбросієм Бучмою. Молода співачка 3 усією відповідальністю і великим бажанням взялася за вивчення партії Наталки та досягнення високого виконавського й акторського рівня. Усі грані характеру, які були притаманні героїні, Зоя усією душею відчула і відтворила у спектаклі. Наступною великою роботою була опера “Катерина” М. Аркаса на сюжет Т. Шевченка.
Для Зої Христич це була перша в ії житті прем’єра в партії Катерини. Тут вона теж зустрілася 3 видатними майстрами оперного мистецтва, постановниками спектаклю - диригентом Я. Карасиком та режисером В. Скляренком. Образ Катерини сповнений драматизму і вимагав іншої акторської гри, глибшого музичного виконання. Велику допомогу в розкритті образу співачці надали режисер і диригент. У цій партії співачка досягає вершин майстерності, різностороннього і правдивого відтворення образу своєї героїні. 3 великим задоволенням 3. Христич співала партію Оксани в опері “Запорожець за Дунаєм” С. Гулака-Артемовського. Це була їі улюблена героїня, яка приваблювала вірністю, ніжністю і патріотизмом. Багато років Зоя Христич виступала у цій виставі на сцені рідного театру. “Три партії Зої Христич у класичному українському оперному репертуарі, три ролі, три образи, які мають багато спільного, і разом з тим - це різні жіночні долі, а для розкриття образу кожної з них від актриси вимагалася неабияка майстерність" - так зазначав автор монографічного видання про творчість співачки Е. Яворський [8, 27].

У 1956 р. молодій співачці запропонували взяти участь у міжнародному конкурсі вокалістів у Женеві, який був відповідальним і хвилюючим, адже у змаганні взяли участь 342 виконавці 3336 країн світу. Виконавиця успішно пройшла три конкурсні тури й голова жюрі Анрі Ганьобін оголосив лауреатом конкурсу солістку Київського театру опери та балету ім. Т. Г. Шевченка Зою Христич і вручив їй диплом першого ступеня. Успіх української вокальної школи був незаперечним як в Україні, так і за пї межами. Після повернення 3. Христич поринула в концертну круговерть: радіовиступи, сольні програми в театрі, гастролі.

У театрі іï чекав наступний дебют - партія Мікаели в опері “Кармен” Ж. Бізе, до якої вона готувалася дуже ретельно: читала книжки про цей твір, прагнула зрозуміти психологію і глибокі почуття героїв, щоб передати глядачам їхні переживання. Глибоко пройнявшись музикою, співачка віднайшла найвиразніші нюанси та відтінки характеру Мікаєли.

Навесні 1958 р. в оперному театрі ставилась вистава “Лоенгрін” Р. Вагнера в постановці диригента О. Климова, режисера В. Скляренка і художника В. Людмиліна. Зоя Христич була призначена на партію Ельзи. Публіка і преса позитивно оцінили прем'єру, особливо була відзначена робота Зої Христич. Пізніше ця складна партія стала однією з їі улюблених. 


\section{СЦЕНІЧНА ДІЯЛЬНІСТЬ ЗОЇ ХРИСТИЧ У КОНТЕКСТІ РОЗВИТКУ ВОКАЛЬНОГО МИСТЕЦТВА УКРАЇНИ}

Визначною подією у житті Зої Христич була участь у всесвітньому фестивалі демократичної молоді і студентів у Відні у липні 1959 р. “Туди прибуло 400 вокалістів із 32 країн світу, серед яких були й Георгій Красуля, Надія Куделя, Діана Петриненко, Зоя Христич. Усі вони не лише отримали високі нагороди, але й не згубилися у часі: стали славою українського мистецтва" [1, 102]. У дні фестивалю відбулося 280 концертів і в одному 3 них виступила Зоя Христич. Вона виконала арію Леонори з опери “Трубадур” Дж. Верді. "Слухачі були вражені широтою виконавських можливостей співачки: м'яке ліричне звучання змінювалось напруженодраматичним і раптом злітало легко, рухливою колоратурою. Зал висловив українській співачці своє захоплення бурхливими оваціями" $[8,46]$.

Тоді ж у Відні в Брамсзалі Музикферайну проходив міжнародний конкурс вокалістів, який очолив видатний італійський оперний співак Тіто Скіпа. На конкурсі вона виконала каватину Норми 3 опери “Норма” В. Белліні, арію Леонори з опери “Трубадур" Дж. Верді, романси та українські народні пісні. Зоя Христич отримала першу премію і золоту медаль лауреата. Тіто Скіпа привітав співачку і зробив сердечний запис на ії нотах $[8,47]$.

Наступним спектаклем, який запланував театр до постановки, була опера "Приборкання непокірної” В. Шебаліна за однойменною комедією В. Шекспіра. Зоя Христич була призначена на виконання ролі Біанки. Співачці кортіло спробувати свої акторські можливості у жанрі комічної опери. Вона мріяла знову працювати $з$ такими видатними митцями, як диригент Веніамін Тольба та режисерка Ірина Молостова. I тут співачка створила своєрідний, глибокий, досить примхливий образ своєї героїні. Виконання цієї партії підтвердило великі акторські здібності співачки.

У 1962 р. Зоя Христич готувалася до міжнародного конкурсу вокалістів у французькому місті Тулуза. Кожен учасник мав підготувати дванадцять творів мовою оригіналу. До програми входили старовинні арії з кантат або ораторій, романси і оперні арії. Перед поїздкою до Тулузи відбулося прослуховування у Москві. За його результатами на конкурс поїхали: з Ленінграда Галина Ковальова і Валерій Малишев і киянки Зоя Христич і Галина Туфтіна. Конкурс проходив в три тури, у третьому з яких 3. Христич співала 3 оркестром арію Норми з однойменної опери В. Белліні. Співачка здобула срібну медаль і звання лауреата.

Цікавою постановкою на Київській сцені була
“Іоланта" П. Чайковського. Колись ця партія для 3. Христич була випробуванням на майстерність в Одеській консерваторії, а тепер на професійній сцені вона повинна заспівати ії на найвищому рівні. Під час праці над оперою зав'язалася творча співдружність 3 прекрасним музикантом К. Сімеоновим, постановником був молодий режисер Ю. Леко. Співачка успішно зуміла передати неусвідомлені поривання молодої героїні та її внутрішній світ.

За здобуття високих нагород на трьох міжнародних конкурсах в Женеві, Відні та Тулузі, за заслуги у розвитку українського вокального мистецтва Зої Христич було присвоєно звання заслуженої артистки України (1962). Це відкривало для молодої співачки нові можливості для розвитку і вдосконалення творчих задумів в оперному і камерному жанрі.

Для виконавиці характерними були образи героїнь $з$ важкою долею. Тому її думки часто зупинялися на партії Маргарити з опери "Фауст" Ш. Гуно. Ця вистава йшла на сцені оперного театру багато років і були відпрацьовані свої традиції. Вокальну партію співачці вдалося опанувати досить успішно, а сценічний образ вдався не відразу. Постановником цієї опери був народний артист України М. Стефанович. “Якщо Михайло Стефанович демонстрував той або інший рух, поворот корпусу, реакцію на музичну репліку партнера, - згадує Зоя Петрівна, - вже важко було уявити собі щось інше або запропонувати своє. Завжди це було настільки переконливо, що навіть не виникало бажання бачити іншу трактовку” $[8,62]$.

Незабаром знову пролунала пропозиція взяти участь у конкурсі молодих оперних співаків у Болгарії в червні 1963 р. У цьому форумі учасниками були оперні співаки з 27 країн світу. Усі три тури конкурсу пройшли з великим успіхом. Серед слухачів була велика кількість прихильників, що активно підтримували співачку, яка в останньому турі співала партію Маргарити в опері “Фауст” Ш. Гуно. Журі високо оцінило іiі вокальне мистецтво, присудивши високе звання лауреата міжнародного конкурсу оперних співаків. Незадовго знову з'являлися нові образи, в яких співачка проявляла свою щирість, жіночу ніжність і шляхетність, високу акторську майстерність, срібний, сповнений душевним теплом, голос.

3 оперою Дж. Верді “Трубадур” Зоя Христич познайомилася ще навчаючись у консерваторії. Співачка виконувала вокальні фрагменти, поставлені в оперній студії при Одеській консерваторії, а також співала арії з цієї опери на міжнародних конкурсах та в концертних 


\section{СЦЕНІЧНА ДІЯЛЬНІСТЬ ЗОЇ ХРИСТИЧ У КОНТЕКСТІ \\ РОЗВИТКУ ВОКАЛЬНОГО МИСТЕЦТВА УКРӒ̈НИ}

програмах. Диригент-постановник спектаклю В. Тольба з великою ретельністю і прискіпливістю ставився до роботи над оперною партією, шукав різноманітні засоби для вдосконалення акторської гри. Це дозволяло співакам повністю виявити свої виконавські можливості. Яскраве і виразне вокальне виконання у поєднанні 3 акторською майстерністю допомогли співачці створити переконливий образ Леонори. Цей спектакль кияни показали у Великому театрі в Москві. І ось що зазначалося в рецензії в журналі “Театральная жизнь”: “Секрет успіху киян простий: вони пристрасно закохалися в оперу, зрозуміли, що сила Верді - в правдивості й людяності. I як це не парадоксально проте в київському спектаклі було більше жару і пристрасті шаленого італійця, ніж у його уславлених співвітчизників (мається на увазі виставу театру Ла Скала. - Е. Я). І ще одна перевага киян: вони досконало володіють мистецтвом злиття музики, співу і драми" $[8,73]$.

Наступною яскравою роллю 3. Христич стала партія Гелени в опері “Богдан Хмельницький” К. Данькевича. Ще на початку навчання в Одеській консерваторії, проходячи повз кабінет директора, Зоя Христич почула чудового тембру баритоновий спів. Мелодії, які виконував співак були подібні до народних і їй здавалось, що вона їх десь чула. Товаришка по навчанню, розповіла Зої, що співає і сам собі акомпанує відомий композитор К. Данькевич. Такий у нього творчий метод роботи над створенням нової опери “Богдан Хмельницький”. 3. Христич розуміла, що партія Гелени написана для драматичного сопрано, а в неї ліричне. Проте ще навчаючись у консерваторії, у неї розширився виконавський діапазон, з'явилася тембральна насиченість голосу, характерна для драматичного сопрано. В iii репертуарі з'явилися й твори драматичного характеру. Тож у 1965 р. Київський театр відновив постановку опери “Богдан Хмельницький” і відомий диригент К. Сімеонов призначив нових виконавців. Партію Богдана Хмельницького співав народний артист СРСР М. Ворвулєв, партію Гелени - 3. Христич. Виконання ролі дружини гетьмана було дуже складним завданням i вимагало великої акторської майстерності. Бо поряд 3 такими рисами, як здатність до щирих і глибоких почуттів, були чарівність-зрада i лицемірство, тобто необхідне вміння переходити 3 одного емоційного і психологічного стану в інший, залежно від сценічної ситуації. Про те як вдавалося співачці поєднувати такі різні партії, вона розповідала: “Вважаю, що такий підхід до репертуару суто індивідуальний. Це пояснюється в першу чергу можливостями голосу, його діапазоном, тембровим забарвленням, насиченістю звучання. А до цього слід додати вже майстерність володіння голосом, уміння не перевтомлювати його і використовувати найбільш вигідно теситурні можливості” $[8,79]$. Так був створений ще один цікавий жіночий образ, який увійшов в історію українського музичного театру. У 1965 р. співачка отримала звання народної артистки України $[4,565]$.

Часто в оперному жанрі зустрічаються невеликі партії глибокого змісту, які вимагають від співака неабиякої обдарованості і акторської віддачі. Зоя Христич теж мала можливість зустрітися з такою характерною партією дівчиниспівачки в опері “Тарас Шевченко” Г. Майбороди. Цей твір, неординарний за драматургічною побудовою, складається 3 чотирьох окремих новел, які об'єднані одним героєм. До кожної новели автор подає епіграф з віршів Т. Шевченка. 3. Христич брала участь у другій новелі 3 епіграфом “Якби ви знали паничі...”. Співачка вклала всю свою душу і ліричне обдарування в свою героїню й одночасно глибоко розкрила іiі трагічну долю. В кінці пісня обривається гірким риданням артистки. Твір був записаний на грамплатівку і поповнив їі дискографію.

3 диригентом В. Тольбою Зоя Христич зустрілася знову в праці над оперою "Чарівна флейта" В.-А. Моцарта - прекрасній казці, де кохання перемагає усі перешкоди, а добро торжествує над злом. Робота принесла співачці успіх і користь в опануванні ансамблевим виконавством, вона отримала велику естетичну насолоду в опануванні моцартівського шедевру.

Часом керівництво театру пропонувало співачці цілком протилежні партії. Після Леонори їй радили співати партію Людмили 3 опери "Руслан і Людмила" М. Глінки, яку виконують колоратурні сопрано. Але широкий діапазон голосу співачки, його легкість і рухливість дали їй можливість подумати про експеримент. В подальшому 3. Христич підготувала ще такі партії, як Недда 3 опери “Паяци” Р. Леонковалло, Дездемона з опери “Отелло” Д. Верді, Галя 3 опери “Назар Стодоля” К. Данькевича та інші.

Авторка монографії “Історія вокального мистецтва” О. Шуляр зазначила, що: “3 кожним роком у постановках опер появлялись все нові й нові імена українських співаків, проте, все ж, найбільшої слави Київський театр опери та балету здобув в той час, коли в ньому працювали славетні співаки М. Микиша, Б. Гмиря, Л. Руденко, П. Білинник, В. Тимохін, 3. Христич, Д. Гнатюк, Н. Кондратюк, А. Мокренко та інші”' [7, 197].

Ще навчаючись у консерваторії, кожен співак визначає для себе творче спрямування - оперне 


\section{СЦЕНІЧНА ДІЯЛЬНІСТЬ ЗОЇ ХРИСТИЧ У КОНТЕКСТІ}

РОЗВИТКУ ВОКАЛЬНОГО МИСТЕЦТВА УКРАЇНИ

чи камерне виконавство. Якщо відразу правильно визначені нахили, тоді це визначає долю співака. Поєднання оперного і камерного виконавства не завжди приносить рівноцінний успіх, адже камерні виконавці майже не стають оперними співаками. У Зої Христич відбувалося успішне поєднання цих амплуа. Виходу Зої Христич на концертну естраду зі сольними концертними програмами передував складний творчий процес. Скільки праці необхідно вкласти, щоб підібрати відповідну програму, щоб у ній була динаміка, розвиток і дотриманий принцип контрасту. Зоя Христич будувала концертні програми за різними принципами. Це були концерти тематичні, стилістичні або збірні на контрастах, де значне місце займали арії з опер та українські народні пісні. В упорядкуванні К. Радченко у 1975 р. вийшов збірник "Українські народні пісні із репертуару Зої Христич” [6]. Це пісні в опрацюванні: М. Лисенка (“Лугом іду, коня веду”, “Ой не світи місяченьку”, “Віють вітри”, “Ой джигуне, джигуне”); Б. Лятошинського (“Ой вербо, вербо”, “Перепеличка овдовіла”, “Зашуміла ліщинонька”); Ф. Надененка (“Гандзя“, “Місяць на небі”); О. Чишка (“Спать мені не хочеться”, “Чом, чом не прийшов”, “Ой гиля білі гуси”); М. Колесси (“Ой є в лузі калина”), В. Косенка (“Баламуте”), Р. Феніха (“Скажи мені правду”), С. Гулака-Артемовського (“Ой казала мені мати").

У репертуарі співачки були твори різних жанрів і епох: Й. Баха, Г. Генделя, В. Моцарта, Ф. Шуберта, Р. Шумана, Р. Штрауса, М. Глінки, П. Чайковського, М. Римського-Корсакова, С. Рахманінова, М. Лисенка, К. Стеценка, Я. Степового та ін. Концерти співачки були детально продумані, вивірені усі нюанси, кульмінації, акценти і сила звуку. За свою високу виконавську майстерність у концертному виконавстві співачка отримувала схвальні рецензії як в українській, так і в зарубіжній пресі.

3 великим успіхом співачка виступила на заключному концерті Декади Української культури у Польщі та декаді української літератури та мистецтва в Угорщині. У 1964 р. Зоя Христич, на запрошення художнього керівника Ленінградської філармонії провела сольний концерт в концертному залі ім. М. Глінки. І ось оцінка цього концерту рецензента! 'ВВечір пройшов з виключним успіхом. Христич володіє поєднанням всіх даних, необхідних співачці: привабливою сонячною зовнішністю жительки півдня, зовнішністю, без якої найкращий спів не переконує слухача, свіжим, теплим звучним голосом, що лине в далечінь, кришталевої чистоти тембром, хорошою школою, виразністю виконання, прекрасним фразуванням, скромною і благородною манерою поведінки на естраді" $[8,89]$.

Під час гастролей у Югославії тодішня преса писала “...З Зоя Христич розкриває в кожній ролі різні образи іiі сопрано є мінливим і вогненним відтворенням живої арфи. Її потрібно дивитись і слухати тому, що кожен рух співачки - єдине ціле" $[8,90]$.

Співачка здійснила низку записів на грамплатівках українських народних пісень (“Гандзя”, “Ой не світи місяченьку”, “Спать мені не хочеться”), а також арії з опер українських та зарубіжних композиторів" $[4,566]$.

Близько п'ятдесяти років 3. Христич успішно працювала як педагог вокалу. Від 1965 р. викладач, 31984 - професор Київської консерваторії. Серед учнів 3. Христич є визнані майстри співу, заслужені та народні артисти України, лауреати престижних конкурсів, солісти провідних театрів співу. Це зокрема: Лідія Забіляста, Володимир Гришко, Людмила Маковецька, Ольга Камінська, Ольга Фомічова, Мері Гревцова, Іва Носик та ін. Володимир Гришко навчався в аспірантурі в класі професора Зої Христич. “Здається, Зоя Петрівна Христич точно розрахувала криву успіху свого вихованця по зростаючій. Справді, “планка” неухильно піднімалася: протягом осені 89-го року всього за три місяці В. Гришко завоював III премію на Міжнародному конкурсі оперних співаків у Марселі, II премію (І премію нікому не присудили) на Всесоюзному ... конкурсі імені Глінки і Гранпрі та спеціальний приз Пласідо Домінго “Тенормілор (“Кращий тенор”) на Міжнародному конкурсі вокалістів у Барселоні Імені Франсіско Віньяса, Іспанія" [2]. Через рік, у 1990, співак здобув "Гран-прі" на Міжнародному конкурсі співаків у Тулузі (Франція), до того ж професор 3. Христич була членом журі цього авторитетного форуму.

Зоя Христич була постійним членом журі багатьох міжнародних конкурсів, які проходили в Україні та за кордоном. Одним із престижних форумів, які проводились в Харкові, був Міжнародний конкурс вокалістів імені Івана Алчевського, який відбувався в рамках міжнародного фестивалю “С. Рахманінов та українська культура” (Харків, 1999) [5, 430], була також президентом фонду Соломії Крушельницької. Співачка, педагог Зоя Христич пішла 3 життя 4 травня 2016 р.

Висновки. Життєве кредо видатної співачки - віддати усі свої сили, талант і уміння рідному народу. Зміст свого життя вона бачила на оперній сцені, в концертних програмах, у громадській та 
педагогічній діяльності. Шкода, що ім'я і творчість славетної української співачки, яка мала блискучий успіх на чотирьох міжнародних конкурсах, яка популяризувала українську музику на кращих сценах України і світу, сьогодні призабуті.

Своїм високим мистецтвом виконавиця приносила чимало радості і захоплення слухачам у концертних залах, на оперній сцені, в програмах радіо і телебачення. Ї̈̈ чарівний голос звучав у всіх областях і районних центрах України, у Москві, Ленінграді, Ташкенті, Алма-Аті та ін. Співачка виступала також в Польщі, Румунії, Угорщині, Німеччині, Болгарії, Югославії, Італії та на Кубі. Виступи 3. Христич, їі блискучі успіхи на міжнародних конкурсах, численні гастролі в різних країнах принесли українській співачці світову славу й стали справжнім тріумфом українського виконавського мистецтва.

\section{ЛIТЕРАТУРА}

1. Антонюк В. Вокальна педагогіка (сольний спів): Підручник. Київ: ЗАТ “Віпол”, 2007. 174 с.

2. Артисти: Гришко Володимир. URL: http:// fcaua.com/index.php?option $=$ com_ listing\&task =view\&id=244\&Itemid=12 (дата звернення: 20 . Feb. 2021)

3. Данькевич К. На щасливу творчу дорогу. Радянська культура. 1956. 11 липня.

4. Лисенко I. Христич Зоя Петрівна. Лисенко I. Співаки України. Енциклопедичне видання. 2-ге вид., переробл. і допов. Київ: Знання, 2011. C. 565-566.

5. Трубнікова Л. Іван Алчевський та міжнародні конкурси вокалістів його імені: в тч. про харк. родину Алчевських. С. Рахманінов на зламі століть: збірник статей. Харків: ФОП Носань В.А., 2008. Вип. 5. С. 424-435.

6. Українські народні пісні з репертуару Зої
Христич / Ред.-упор. К. Рядченко. Київ: Музична Україна, 1975. 64 с.

7. Шуляр О. Історія вокального мистецтва: Монографія: Ч. ІІ. Івано-Франківськ, 2013. 360 с.

8. Яворський Е. Зоя Христич. Київ: Музична Україна, $1975.96 \mathrm{c.}$

\section{REFERENCES}

1. Antoniuk, V. (2007). Vokalna pedahohika (solnyi spiv): Pidruchnyk [Vocal pedagogy (solo singing): Textbook]. Kyiv, 174 p. [in Ukrainian].

2. Artists: Grishko Vladimir. Available at: http:// fcaua.com/index.php? option $=$ com _listing\&task $=$ view\&id=244\&Itemid=12 (Accessed 20. Feb. 2021). [in Ukrainian].

3. Dankevych, K. (1956). Na shchaslyvu tvorchu dorohu [On a happy creative path]. Soviet culture. July 11. [in Ukrainian].

4. Lysenko, I. (2011). Khrystych Zoia Petrivna [Khrystych Zoya Petrovna]. Lysenko I. Singers of Ukraine. Encyclopedic edition. 2nd ed., reworked. and add. Kyiv. pp. 565-566. [in Ukrainian].

5. Trubnikova, L. (2008). Ivan Alchevskyi ta mizhnarodni konkursy vokalistiv yoho imeni: $v$ tch. pro khark. rodynu Alchevskykh [Ivan Alchevsky and international competitions of vocalists named after him: incl. about Kharkiv. the Alchevsky family]. S. Rachmaninoff at the turn of the century: a collection of articles. Kharkiv. Vol. 5.pp. 424-435. [in Ukrainian].

6. Ukrainski narodni pisni z repertuaru Zoi Khrystych (1975). [Ukrainian folk songs from the repertoire of Zoya Khrystych]. (Ed.). K. Ryadchenko. Kyiv, 64 p. [in Ukrainian].

7. Shuliar, O. (2013). Istoriia vokalnoho mystetstva: Monohrafiia [History of vocal art: Monograph]. Part II. Ivano-Frankivsk, 360 p. [in Ukrainian].

8. Yavorskyi, E. (1975). Zoia Khrystych [Zoya Hristic]. Kyiv, 96 p. [in Ukrainian].

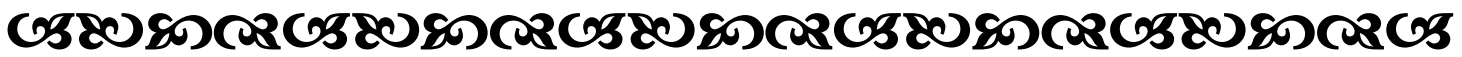

\author{
"ТТворець художнього твору майбутнього є не хто інший, як художник \\ теперішнього часу”. \\ Вагнер Piхард \\ німецький композитор
}

"Навряд чи взагалі є щось гідніше, яК вдосконалювати свій дух, увічнювати себе в свойх творіннях і дарувати їхнащадқам”.

Олесь Тончар

уқрайнсьқий письменник, літературний критик

\section{G58080}

